\title{
Empathy for the psychological underdog: A positive psychological approach to Luke's Gospel
}

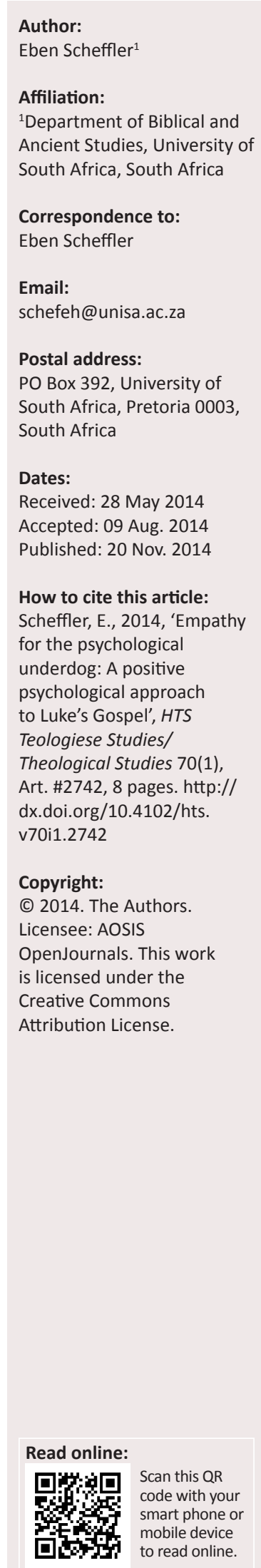

Taking the lead from Wisdom of Solomon 7:20, which clearly indicates that ancient authors did engage in the specialised 'scientific' (although contemporary) study of mental processes

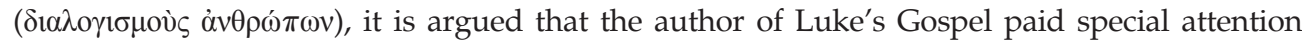
to the alleviation of human psychological suffering. Employing an approach recently being labelled as 'positive psychology', attention will be paid to general affliction (e.g. Lk 4:18; 6:21, 25), old age (Lk 1:5-80; 2:25-38), grief (e.g. Lk 7:11-17) and the emphasis on mental processes in Luke's portrayal of Jesus' exorcisms (e.g. Lk 4:35; 6:18-19; 9:38), as well as the psychological dimension involved in other types of suffering (e.g. poverty, sickness, enmity and social ostracism). The 'mental process', 'feelings' or 'empathy' that motivate the alleviation of suffering (in the behaviour of Jesus and his followers) will also come into focus in the discussion

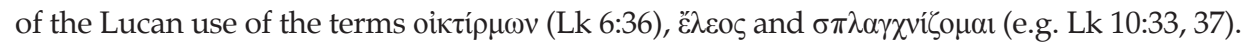

\section{Introduction}

When researchers call Luke 'den Psychologen unter den neutestamentlichen Schriftstellern' (Du Toit 1965:26 - 'the psychologist amongst the New Testament authors'), it by no means implies anachronistically that Luke had all the knowledge that the past 150 years of scientific psychology gathered - not even in embryo. On the other hand, we as present-day 'scientific' researchers should not be so arrogant as to think that ancient authors did not make a conscious effort to study the different spheres of reality, or that they did not do it intelligently. Gerhard von Rad (1970:30) drew attention to the fact that conscious study of reality formed part and parcel of the late Jewish wisdom tradition. According to Von Rad (1970:30) the book of Proverbs contains wisdom for ordinary life which only forms a small part of a comprehensive quest for knowledge

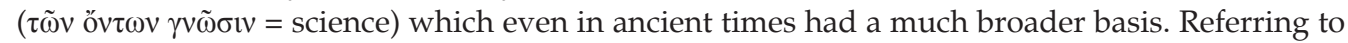
Wisdom 7:18-20 (which dates between 100 BCE and 100 CE) he consciously employs presentday scientific terms:

In den späten Buch der Weisheit Salomos werden den einmal einzelne Fächer der damals gelehrten Naturwissenschaften aufgezählt; es sind dies Astronomie, Zoologie, Dämonologie, Psychologie, Botanik und Pharmazie (SapSal 7:18ff). Es ist kaum anzunehmen, dass alle diese Wissensgebiete den Lehrern erst in den spätesten Phase zugewagchsen sind. (Von Rad 1970:30)

The relevant text from Wisdom can be seen in Table 1.

Interestingly, the term $\delta 1 \alpha \lambda o \gamma ı \sigma \mu o$ in verse 20 and verses $21-22$ (cf. the reference to 'what is

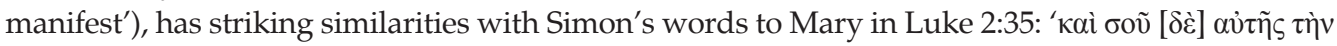

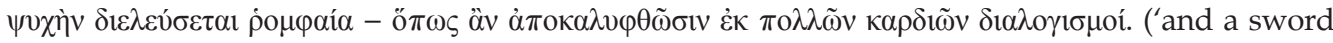
will pierce your soul too - so that the secret thoughts of many may be laid bare).' Numerous other instances may be mentioned which reflect a similar psychological interest in people's 'thoughts'.

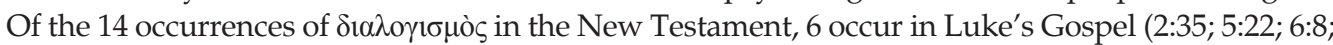
$9: 46 ; 9: 47 ; 24: 38)$. Jesus is especially portrayed as knowing peoples thoughts $(5: 22 ; 6: 8 ; 9: 47 ; 24: 38)$.

\section{On positive psychology}

In what follows I hope to show that positive psychology, a psychological approach that has developed recently, provides an appropriate interpretative method of tapping into Luke's psychological insight..$^{1}$ In fact - to my mind - the Gospel in a certain sense can be regarded as providing rudimentary notions for this approach. But what is positive psychology?

An 800 page (A4, double column) volume appeared in 2005 in which various authors made various contributions on relevant themes from a positive psychological perspective (Snyder \&

1.In my doctoral dissertation, Suffering in Luke's Gospel, I distinguished and discussed 'psychological suffering' as one of six dimensions of suffering that Luke emphasised (Scheffler 1993:90-96). Positive psychology, as a specific psychological approach, only appeared on the scene later (Butler-Bowdon 2007:254-259; Seligman 2002, 2005:3-9; Collin et al. 2012:200-201) and therefore this article comprises an extended refinement of the discussion in my dissertation. 
Lopez 2005). ${ }^{2}$ According to Seligman, ${ }^{3}$ who is regarded as a major founder of this approach, (positive psychology aims at 'catalys $[i n g]$ a change in psychology from a preoccupation only with repairing the worst things in life to also building the best qualities in life' (Seligman 2005:3). ${ }^{4}$

2.Because of its almost encyclopaedic nature, and for the purposes of this contribution, I confine myself mainly to this volume, although some other relevant psychological works will also be referred to.

3.Seligman once served a term as chair of the American Psychological Association, which testifies to the wider recognition of his work.

4.Interestingly, there also exist similar voices outside the 'school' of positive psychology who criticise 'biomania' and highlight values, relationships and the ethics of care (e.g. Allen 2013:105 referring to the work of Bracken et al 2012:432)

TABLE 1: The translation of Wisdom 7:17-20.

\begin{tabular}{|c|c|}
\hline Wisdom 7:17-20 (LXX) & Wisdom 7:17-20 (NRSV) \\
\hline 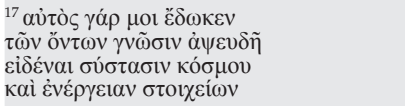 & $\begin{array}{l}{ }^{17} \text { For it is he who gave me } \\
\text { unerring knowledge of what exists, } \\
\text { to know the structure of the world } \\
\text { and the activity of the elements; }\end{array}$ \\
\hline 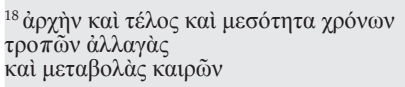 & $\begin{array}{l}18 \text { the beginning, end and middle of times, } \\
\text { the alternations of the solstices } \\
\text { and the changes of the seasons, }\end{array}$ \\
\hline 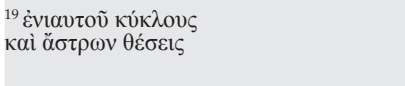 & $\begin{array}{l}{ }^{19} \text { the cycles of the year } \\
\text { and the constellations of the stars } \\
\text { (astronomy) }\end{array}$ \\
\hline 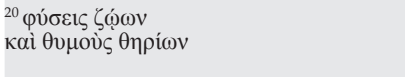 & $\begin{array}{l}{ }^{20} \text { the natures of animals } \\
\text { and the tempers of wild animals } \\
\text { (Zoology). }\end{array}$ \\
\hline 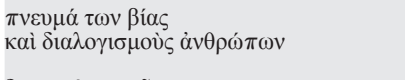 & $\begin{array}{l}\text { the powers of spirits(demonology) } \\
\text { and the thoughts of human beings } \\
\text { (psychology), }\end{array}$ \\
\hline 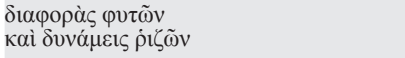 & $\begin{array}{l}\text { the varieties of plants (botany) } \\
\text { and the virtues of roots (pharmacy) }\end{array}$ \\
\hline 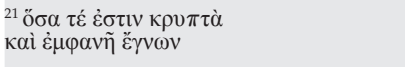 & $\begin{array}{l}{ }^{21} \text { I learned both what is secret } \\
\text { and what is manifest, }\end{array}$ \\
\hline 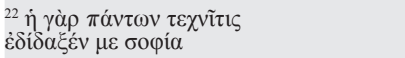 & $\begin{array}{l}{ }^{22} \text { for wisdom, the fashioner of all things, } \\
\text { taught me. }\end{array}$ \\
\hline
\end{tabular}

Note: In the English translation, items in brackets indicate the discipline being referred to.
The fathers of traditional psychology (e.g. Wundt, Freud, Jung $^{5}$ ) were medical practitioners working with a disease model that seeks to cure diseases by treating symptoms with special medicine-like treatment (e.g. psychoanalysis, behaviour therapy). Positive psychology focuses on the 'building of strengths' and does not deny treatment, but also develops aspects that prevent mental illness and enhance the quality of life. ${ }^{6}$ Psychology should not merely help one to cope with the afflictions of life, but to enjoy life to the full. ${ }^{7}$ Seligman (2005) continues:

The field of positive psychology at the subjective level is about positive subjective experience: well-being and satisfaction (past); flow, joy, the sensual pleasures, and happiness (present); and constructive cognitions about the future - optimism, hope and faith. At the individual level it is about positive personal traits - the capacity for love and vocation, courage, interpersonal skill, aesthetic sensibility, perseverance, forgiveness, originality, future-mindedness, high talent, and wisdom. At the group level it is about the civic virtues and the institutions that move people towards better citizenship: responsibility, nurturance, altruism, civility, moderation, tolerance, and work ethic. (p. 3)

Seligman (2005:7) concedes that as far as traditional psychology is concerned positive psychology has affinities

5.For a brief overview of their approaches, see Collin et al. (2012:32-37; $92-99$ 101-107).

6.The medical 'diagnostic' approach finds a classical expression in the Handbook of abnormal psychology (Eysenck 1973), whose various contributions all reflect that very approach (e. criminal behaviour, drug dependence, abnormal sexual behaviour approach (e.g. criminal behaviour, drug dependence, abnormal sexual behaviour, abnormalities of perception, motivation and learning etc.). In terms of the traditiona approach the term 'normal psychology' could be an alternative term used, preventing
the positive approach from completely denying psychological defects.

7.Cf. also Fueter's (1986:309-319) penetrating (and relevant for positive psychology without referring to the latter) discussion and distinction between the language of science or 'diagnosis' and the language of healing.

TABLE 2: Themes considered in positive psychology and also present in Luke's Gospel.

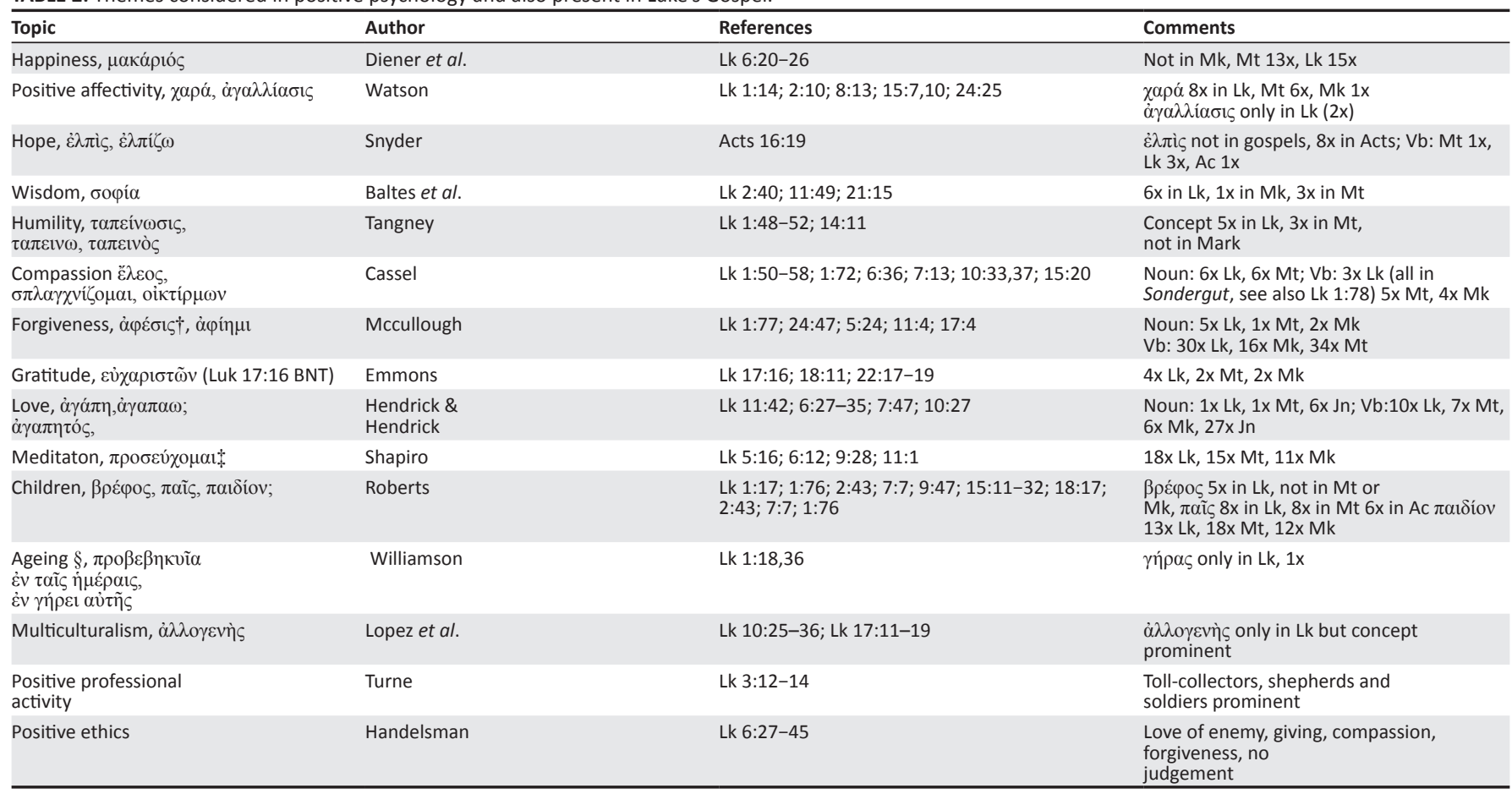

$\dagger, \dot{\alpha} \varphi \varepsilon ́ \sigma ı \varsigma$ does not always refer to forgiveness of sins as a pure religious act, but also to 'release', 'liberation' and even 'divorce'.

\$, To relate prayer to meditation is, of, course debatable. However, Luke often portrays Jesus as going to a lonely place in nature to spend time in prayer to God. Within Jewish context this most likely included meditation. The references given in the table are to these instances.

$\S$, The word for old age ( $\gamma \eta$ ṕac) occurs only once in the New Testament (Lk 1:36), but the motif is often present and presupposed (as in the case of Simon in Lk 1:26), or expressed in a phrase by

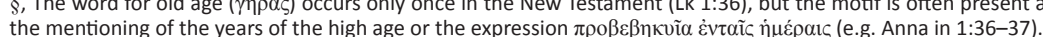


with the work of Allport (1961) and Maslow (1970, 1971 the latter distinguishing the need for positive self-fulfilment as an ultimate goal in life). ${ }^{8}$ However, as I hope will become clear, positive psychology goes beyond the fulfilment of any personal individual human need.

The various contributions in the Handbook of positive psychology reflect approximately 47 issues on which positive psychology focuses, as well as several theoretical contributions on the subject. Many of these topics, or themes, are directly present in the Gospel of Luke, and nearly all are indirectly related to the Gospel. Table 2 contains a selection of themes that receive focused attention, directly traced in the Gospel of Luke (and/or Acts) or related to it. ${ }^{9}$

It is clear from the statistics above (column 4, Table 2) that in nearly all cases these themes feature more prominently in Luke's Gospel than in the other Gospels and Acts. Even so, it should be kept in mind that differences are to be expected between Luke's view on a particular topic and that proposed by positive psychology on the same topic. But there are surely also striking similarities. Given the status of the Lucan text (as scripture of a religion to which a third of today's world population belongs), it seems proper that the views of the Gospel could at least be accommodated in the discourse regarding a specific theme, especially since the concepts studied by positive psychology are in many instances (cf. Table 2) literally the same, a situation that did not exist in traditional psychology.

In what follows, attention will be paid to ageing and compassion (empathy and altruism included). But as already said, positive psychology addresses and does not deny negative mental states. We will therefore first turn our attention to some of these, briefly indicating the terrain, without any claim to complete treatment.

\section{General affliction (Lk 4:18; 6:21, 25)}

In Luke's programmatic Nazareth episode (4:18) the terms

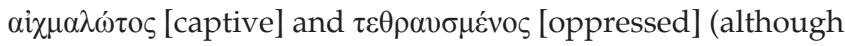
being quoted from Isaiah 61) are best interpreted to refer, in view of the Capernaum episode that follows, to sickness and demon possession (Scheffler 1993:39). Despite these possible

8.For a brief overview of the approaches of Allport and Maslow, see Collin et al. (2012:138-139; 306-313) and Hjelle and Ziegler (1976:171-210; 249-286). To my mind Maslow's humanistic psychology is closer to positive psychology than All port's trait theory (which focuses on individuality, but positively emphasises rationality, proactivity and heterostasis - 1976:207). Maslow's fifteen features of self-fulfilmen define its overlap with positive psychology: self-fulfilled persons (1) perceive reality sufficiently and tolerate uncertainty, (2) accept themselves and others fo what they are, (3) are spontaneous in thought and action, (4) are problem-centred instead of self-centred, (5) have an unusual sense of humour, (6) are able to look at life objectively, (7) are highly creative, (8) are resistant to enculturation but no purposely unconventional, (9) are concerned with the welfare of humanity, (10) are capable of deep appreciation of basic life-experiences, (11) establish deep satisfying interpersonal relationships with a few people, (12) undergo peak experiences, (13) have a need for privacy, (14) support democratic attitudes and (15) have strong moral and ethical standards.

9.Other themes investigated in positive psychology (not mentioned in the table), include: human strengths, resilience in development, the concept of flow, positive emotions, self-esteem, coping, emotional intelligence, (emotional) creativity, personal control, self-esteem, (mindful, ess), optimism, self-efficacy, adjustment, well-being (mindfultioss), passion for knowledge, reality negotiation, authenticity (in social relationships), uniqueness seeking, personal relationships, empathy and altrulsm, moral motivation, toughness, positive affect, integrative science, social support, shaning the story, benefit-finding, meaningfulness, humour, spirituality, positive growth and constructivism (Snyder \& Lopez 2005). Many of these themes overlap, but they represent different perspectives which all have one purpose: to enhance psychological well-being. concrete references, the terms do not lose their general meaning of overall psychological suffering. According to Klein (2006:189), both these words 'sind geistig-geistlich zu

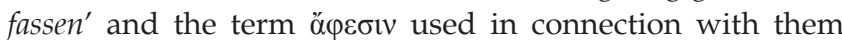
refer in this context not only to forgiveness but 'Entlassung' (release, freedom). Captivity and oppression in this sense are taken to refer to psychological affliction caused, for instance, by sickness, demon possession, poverty or any other kind of suffering. This psychosomatic aspect is emphasised by positive psychology. Cassell (2005:443-444), a medical doctor writing on compassion, emphasises that, because a human being is a person and not only a body, there is a psychological dimension to any bodily sickness. For him it is a good doctor's task not only to treat a sick person's physical symptoms, but to do so with compassion.

In Luke's Gospel, the beatitudes (Lk 6:20-26) are best interpreted as referring to states of suffering rather than virtues, as in Matthew's Gospel. Luke's third beatitude

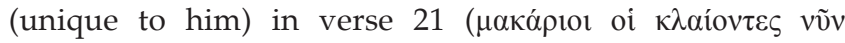
- 'blessed are those that weep', cf. also the $\pi \varepsilon v \theta \eta \dot{\sigma \varepsilon \tau \varepsilon}$

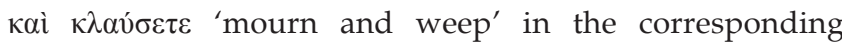
woe of verse 25) also seems to refer to a general state of psychological suffering, an 'Ausdruck der Bekümmernis', ('an expression of worry' - Grundmann 1974:143). The psychological suffering could have been caused by the particular forms of suffering referred to in the other beatitudes, for example poverty ${ }^{10}$, hunger and persecution (or by any other condition for that matter). For all kinds of suffering are in the end interrelated, and affect a person psychologically, exacerbated by the fact that human beings think and ponder about them (Wolter 2008:249).

In this context Luke's peculiar narration of the raising of the widow's son in Nain (recalling the raising of the widow's son by Elisha in 2 Kings 4) can also be mentioned (7:11-17). The focus is not so much on the raising itself as on the widow's grief in losing her son. It is emphatically mentioned

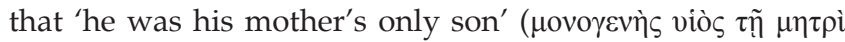
aviov). Jesus' compassion towards her elicits the miracle and it is explicitly stated in verse 13: 'When the Lord saw her, he had compassion for her ( $\left.\dot{\varepsilon} \sigma \pi \lambda \alpha \gamma \chi v i ́ \sigma \theta \eta \dot{\varepsilon} \pi^{\prime} \alpha \hat{v} \tau \eta\right)$ and

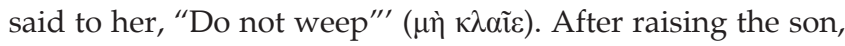
it is also explicitly mentioned that 'Jesus gave him to his

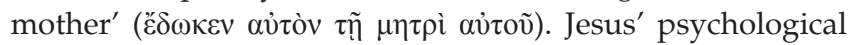
engagement with the mourning mother is clear. ${ }^{11}$

Also unique to Luke is Jesus' concern for the women who lamented him on his way to the cross, when he ironically directs their attention away from his own suffering to theirs and their children (23:28). To my mind Ellis's (1974:266) observation that the women acted from religious obligation, underplays the sincerity of their feelings on a psychological level. The same holds also true for Grundmann's (1974:429) remark that Jesus 'ist über sein Geschick erhoben' (cf. also 1974:429).

10.Poverty is generally regarded as a major theme of the Gospel. For a penetrating study of this dimension of Luke's emphasis on human suffering, see Scheffler study of th
(2011).

11.For a profound 'psychological' commentary on this passage, see Drewermann (2009:479-494). 


\section{Old age as a predicament and ageing well as an opportunity}

In the Handbook of positive psychology Williamson (2005:676-686) wrote an article on ageing well in which he argues that ageing need not be regarded (by elderly people or members of society) as a burden to society, even though it increases the number of older people in it. On the contrary, by adopting certain attitudes (e.g. continuation of meaningful activities ${ }^{12}$ ) old people need not experience their age as a predicament or a disability, but even as a blessing and privilege. ${ }^{13}$

In all probability, this optimistic attitude was not prevalent in Luke's day where the handicaps of old age took their toll. Old people feature in Luke's narrative more than they do in any of the other gospels. Although ageing is primarily a physical process, Luke's positive interest seems to be in the psychological plight of old people.

The sub-discipline of developmental psychology makes a special study of the way old people experience the ageing process ${ }^{14}$. The investigation of life's phases by Erikson (who expanded Freud's five life ${ }^{15}$ stages to include the whole span of human life) seems to be relevant for Luke's emphasis on old age. Erikson distinguishes eight phases ${ }^{16}$ (a recently published book distinguishes $12^{17}$ ), the last of which (above 65 years) constitutes what Erikson calls 'maturity' (see Hjelle \& Ziegler 1976:76). A happy old age is marked by 'ego integrity' and wisdom, whereas an unhappy one is marked by despair and disgust. Ego integrity 'arises from the individual's ability to glance back on his or her life in full perspective ... and humbly but assuredly affirm "I am satisfied"' (Hjelle \& Ziegler 1976:76).

Luke introduces two sets of old people in his Gospel, Zecharaiah and Elizabeth (1:5-80) and Simeon and Anna (2:25-38). In the case of the former it is explicitly mentioned that they were 'advanced in years' (1:7). Because Zechariah was a law-abiding priest belonging to the middle class

12.To continue with what one can do best and which gives one joy seems, according to positive psychology, to be the apt strategy for the aged. But there should be a conscious decision to do just that and not to reflect negatively on the ageing process. H.H. Ellens ([SBL St Andrews] oral comm., July 2013) remarked during discussion time when I delivered this paper at the SBL in St Andrews: 'Traditional psychology asks the 'patient', "What is wrong?", positive psychology asks, "What are you going to do with the time left?"'

13.Lyrically expressed by the German novelist Hermann Hesse (2012:24): 'Wir alten stehen erntend am Spalier/Und wärmen uns die sommerbrauenen Hände./Noch lacht der Tag, noch ist er nicht zu Ende,/Noch hält und schmeichelt uns das Heut und Hier.'

14.See, for example, Kimmel (1974:343-381) for a penetrating discussion of the theories regarding ageing and mortality, the role of disease in the ageing process, physiological changes that come with ageing and changes in intellectual processes in ageing.

15.Freud's five stages are labelled oral, anal, phallic, latent and genital (Hjelle \& Ziegler 1976:31-36).

16.Erikson, in his ground breaking book Childhood and society (1963) labels his eight stages, infancy (0-1 years), early childhood (1-2 years), play age (3-5), school age (6-11 years), adolescence (12-), young adulthood (20-25), middle adulthood (25-65) and maturity (65+). For a summary see Hjelle and Ziegler (1976:63-77).

17.Armstrong's (2007) stages are (1) prebirth, (2) birth, (3) infancy, (4) early childhood, (5) middle childhood, (6) late childhood, (7) adolescence, (8) early adulthood, (9) midlife, (10) mature adulthood, (11) late adulthood, (12) death and dying, (13) beyond death.
(Jeremias 1974:104), they were not suffering in an economic or spiritual sense (the latter referring to being branded as a sinner, see Scheffler 1993:96-101). The old couple was childless, which, besides the psychological implications, was also (according to contemporary belief) regarded as divine punishment (Grundmann 1974:49). Zechariah's answer to the angel ('How should I know this? For I am an old man and my wife is advanced in years $[\pi \rho \circ \beta \varepsilon \beta \eta \kappa v i ̃ \alpha$

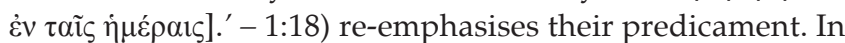
this context, Elizabeth's pregnancy denotes an alleviation of acute suffering. Again old age is emphasised, this time by the angel who announced Jesus' birth to the younger Mary: 'Elizabeth ... who was called barren ... in her old age [ $\dot{\varepsilon} v \gamma \eta \dot{\rho} \rho \varepsilon 1 \alpha \dot{\tau} \tau \tilde{\zeta}]$ has conceived a son' (1:36). Instead of a despairing old age, Elizabeth could therefore experience what Erikson calls 'ego integrity', and she expresses this in the words: 'The Lord has done this for me, now that it has pleased him to take away the humiliation I suffered

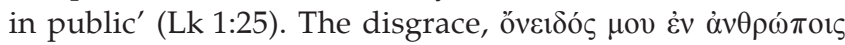
(Lk 1:25) testifies to the shamefulness of childlessness in contemporary society, and intensifies the psychological suffering of being old. To be old is one thing, to be old and childless was considered totally meaningless. Zechariah's utterance of the Benedictus as a whole (Lk 1:68-79) can, in a similar way, also be interpreted as an expression of his ego integrity.

Without going here into detail, the narration of Simeon and Anna's experiences ${ }^{18}$ in 2:25-38 also reflects empathy with their predicament as old people. As with the case of Elizabeth and Zechariah, their predicaments are ultimately relieved with ego integrity as a consequence, as expressed in Simeon's words ' $[n]$ ow you are letting your servant go in peace as you promised; for my eyes have seen the salvation which you have made ready in the sight of the nations' (Lk 2:29-31). As far as Anna is concerned, it is explicitly

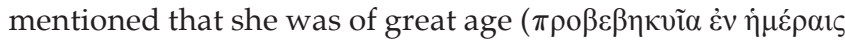
$\pi \mathrm{o} \lambda \lambda \alpha i \bar{\varsigma}$ ) '... a widow till she was eighty four'. Like Simeon, she was eagerly expecting the redemption of Jerusalem, and her giving thanks to God at Jesus' presentation amounts to ego integrity. By including these unique traditions, Luke did not merely show an interest in the ageing process, but also in the psychological alleviation of the affliction of old people. In our present-day world solving their problems in miraculous ways is surely not on the table. However, the evangelist's involvement should be shared, looking for appropriate modern ways of alleviating the psychological burdens of the aged.

\section{Luke's emphasis on mental processes in his portrayal of Jesus' exorcisms (Lk 6:18-19; 4:35; 8:26-39; 9:37-43)}

Luke transmits three of Mark's four exorcisms and does not add any from his Sondergut or Q. However, his enhanced psychological interest is reflected in the fact 18.For a more detailed discussion see Scheffler (1993:91). 
that, in three cases of physical healing (Peter's mother in law's fever in 4:38-39, the dumb man of 11:14 and the crippled women 13:11), the sickness is ascribed to a demon, contrary to his sources).

Before paying brief attention to the exorcisms (the Capernaum demonic, the Gerasene demoniac and the epileptic boy) a comparison of his summary of the healing of the demon possessed in 6:18-19 with that of Mark (3:10-12) reveals a remarkable psychological interest (see Table 3).

Unlike Mark, Luke explicitly mentioned that the people were

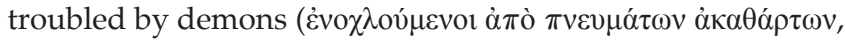
$6: 18 b)$. Mark focuses on the demons falling before Jesus confessing him as the son of God. The actual healing of all

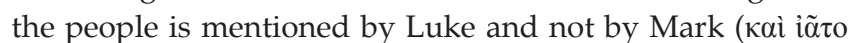
$\pi \alpha \dot{v} \tau \alpha \varsigma, 6: 19)$. It seems, therefore that in Mark's view the actual healing of the demon-possessed persons, and their psychological suffering, was secondary to the fact that Jesus had authority over demons, whereas Luke has no interest in Mark's possible theological motif of the messianic secret. For him (Luke), the suffering of the psychological underdog is paramount and his view rectifies Mark's by stressing Jesus' alleviation of the suffering of all ( $\pi \alpha \dot{v} \tau \alpha \varsigma)$ those who were sick and demon possessed.

In Luke's editing of at least two of Mark's four exorcisms his emphasis on the alleviation of psychological suffering also surfaces clearly. He made significant changes to his Marcan source to reflect Jesus' unconditional compassion for the persons who were demon possessed. Firstly, in Mark 1:26 it is stated that the unclean spirit convulsed ( $\sigma \pi \alpha \rho \alpha \dot{\xi} \alpha v)$ the Capernaum demoniac before it came out. In contrast to this, in Luke 4:36 the casting out is pictured as a less painful process: the demon threw the man in the midst of them ( $\dot{\rho} \tilde{\psi} \psi \alpha v$ instead

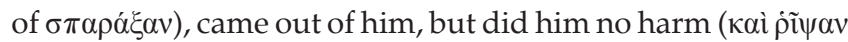

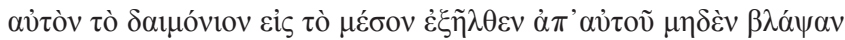

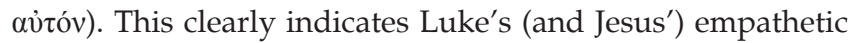
concern. Second, in the exorcism of the Gerasene demoniac

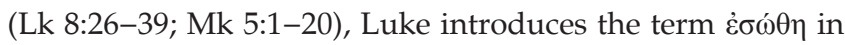
Luke 8:36 to underscore the deliverance of the demoniac - in modern terms, psychological liberation or healing. ${ }^{19}$ After the healing, the healed boy's positive inclination towards Jesus is emphasised by the words 'sitting at Jesus' feet' (Mk 5:15 has 'sitting there') and he is also depicted as fully obeying Jesus (Lk 8:38-39, contra Mk 5:19-20).

19.For a relevant modern treatment of the concept 'Psychische Befreiung' (psychological liberation) along with 'politische Befreiung' (political liberation), inspired by the Christ event, see Moltmann (1973:268-315).
By shortening Mark's version of the healing of the epileptic boy (Lk 9:37-43a; Mk 9:14-27), Luke retains the focus on the actual healing of the boy. As in Mark, the boy's suffering (clearly a grand mal epileptic attack, cf. Suinn 1975:391-392) is described in detail in Table 4.

However, Mark's version elaborates much more on the unbelief of the disciples and the (lack of) faith of the boy's father. If one compares Mark 6:5 with 9:23, Mark seems to see a close connection between faith and healing. Here too Luke plays down the close connection between faith and healing as he did with his creative reinterpretation of Mark's Nazareth episode in Luke 4, thereby emphasising that for Jesus there are no conditions and boundaries to God's mercy for, and compassion towards, those who suffer.

Of special significance is also Jesus' interpretation of the coming of the kingdom of God, not as an apocalyptic event (contra Mark and Matthew) but as happening here and now when psychological healing is affected: 'But if it is by the finger of God that I cast out the demons, then the kingdom of God has come to you' (Lk 11:20). This correlates perfectly with Luke 17:20-21 where the kingdom is explicitly described in psychological terms:

The kingdom of God is not coming with things that can be observed; nor will they say, "Look, here it is!" or "There it is!" For, in fact, the kingdom of God is among you. (Lk 17:20-21) ${ }^{20}$

\section{Compassion, empathy and altruism}

In the Handbook of positive psychology, Cassell (2005:434-445) wrote a chapter on compassion, whilst Batson, Ahmad, Lishner and Tsang (2005:485-498) wrote on empathy and altruism. For the purposes of our interpretation of Luke, compassion can be regarded as an exchangeable term for empathy. Batson et al. (2005:486) define empathy formally as 'an other-orientated emotional response elicited by and congruent with the perceived well-fare of someone else'. Batson et al. (2005) emphasise that true empathy is basically

20.This text caused the Irish author George Bernard Shaw to comment: "Jesus said "The kingdom of God is among you" - ever since the Church has sought for it somewhere else.'

TABLE 4: The epileptic boy in Luke.

\begin{tabular}{|c|c|}
\hline Luke 9:39 & Luke 9:39 \\
\hline 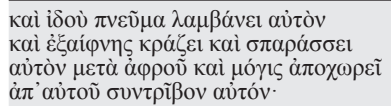 & $\begin{array}{l}\text { Suddenly a spirit seizes him, and all at } \\
\text { once he shrieks. It convulses him until he } \\
\text { foams at the mouth; it mauls him and will } \\
\text { scarcely leave him. }\end{array}$ \\
\hline
\end{tabular}

TABLE 3: Comparison between the demon possessed of Mark and Luke.

\section{Mark 3:10-12}

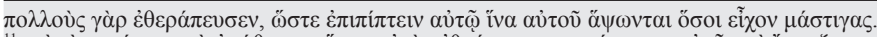

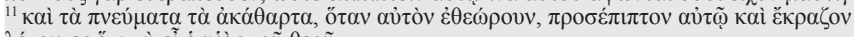

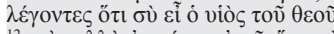

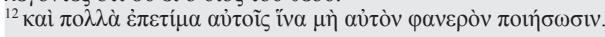

... for he had cured many, so that all who had diseases pressed upon him to touch him. ${ }_{11}^{11}$ Whenever the unclean spirits saw him,

they fell down before him and shouted,

"You are the Son of God!"

${ }^{12}$ But he sternly ordered them

not to make him known.

\section{Luke 6:18-19}

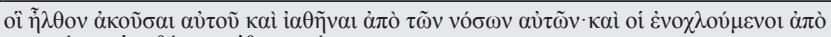

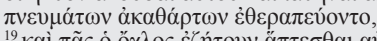

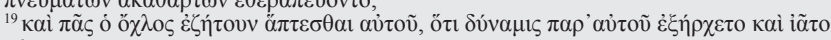
$\pi \alpha \dot{v} \tau \alpha \varsigma$.

They had come to hear him and to be healed of their diseases;

and those who were troubled with unclean spirits were cured.

${ }^{19}$ And all in the crowd were trying to touch him, for power came out from him and healed all of them. 
altruistic, leads to concrete action that benefits people who are suffering, and is not done for egoistic reasons. They quote Pilavin and Charng (1990:27) who contend on the basis of several studies conducted that:

There appears to be a 'paradigm shift' away from the earlier position that behaviour that appears to be altruistic must, under closer scrutiny, be revealed as reflecting egoistic motives. Rather, theory and data now being advanced are more compatible with the view that true altruism - acting with the goal of benefiting another - does exist and is a part of human nature. (Pilavin \& Charng 1990:270 in Batson et al. 2005:490)

In Luke's Gospel, the notion of compassion and altruistic empathy is expressed by the terms $\varepsilon^{2} \lambda \varepsilon_{0}(\operatorname{Lk} 1: 50,54,58$,

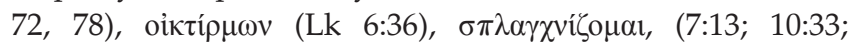
15:20; Ac 1:18) and $\dot{\varepsilon} \pi \mu \varepsilon \varepsilon \lambda \varepsilon \sigma \theta \alpha$ ( to care - Lk 10:34-35). Luke employs three characters (Mary, Zecharaiah and Jesus) to promote it.

In Mary's Magnificat (in all probability based on Hannah's

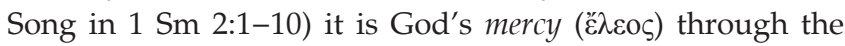
ages (1:50) that finds expression in the reversal of roles of the poor and the mighty in 1:51-53, and which would benefit Israel (1:54). Zecharaiah's Benedictus also refers to the mercy shown to Israel's ancestors (1:72), which also provides the basis for the salvation that would come from his son's follower, Jesus (1:78).

In a programmatic saying as part of the Lucan Jesus' sermon on the plain, which advocates action that benefits sufferers, Luke

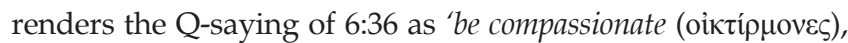
as your father is compassionate (oiktip $\mu \omega v$ )', instead of the 'you

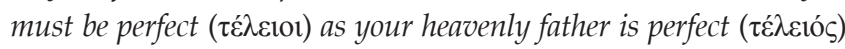
of Matthew 5:48. This notion of God as primarily merciful is not always consistent with (violent) images of YHWH (e.g. as

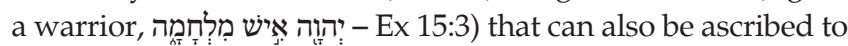

the Jewish and Israelite tradition, although it is not absent in the Old Testament either (cf. Ex 34:6-7) ${ }^{21}$.

Luke furthermore portrays a Jesus who is motivated by the same compassion which is ascribed to God and who expects his followers to be likewise motivated. In the raising of the son of the widow of Nain, it is stated that Jesus was moved with pity for the widow ( $\dot{\varepsilon} \sigma \pi \lambda \alpha \gamma \chi v i \sigma \theta \eta$ $\left.\dot{\varepsilon} \pi^{\prime} \alpha \tau^{\prime} \tilde{y}, 7: 13\right)$ and that he acted as a result of this pity or compassion, in word ('do not weep') and deed (the raising of the son). ${ }^{22}$ That he expected his followers to do likewise in a multicultural context (cf. the work on multiculturalism by Lopez et al. 2005) is nowhere more prominently communicated than in the parable of the good Samaritan (10:33-35). Contrary to the Jerusalem clergy, the Samaritan was moved with compassion ( $\Sigma \alpha \mu \alpha \rho i \tau \eta \varsigma ~ \dot{\varepsilon} \sigma \pi \lambda \alpha \gamma \chi v i ́ \sigma \theta \eta)$ and cared immediately and extensively for the assaulted man (money-wise included). To describe the compassion and the resultant deed as one action, which emphasises their

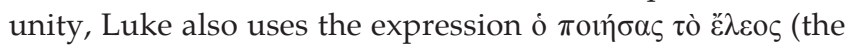

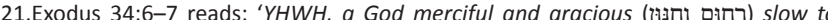

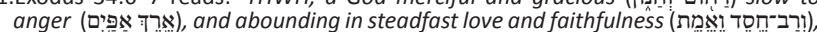

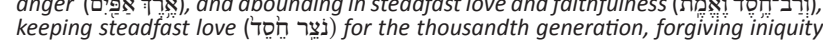

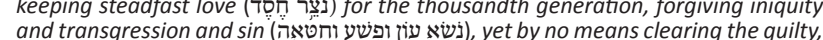

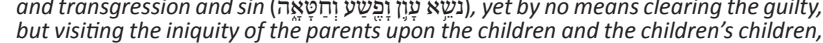
but visiting the iniquity of the parents upon the children and the children's children,
to the third and the fourth generation.' The text is clearly contradictory (not so to the third and the fourth generation.' The text is clearly contradictory (not so
according to Fensham 1970:229), portraying God as both merciful and forgiving, as well as punishing. The first part can be regarded as the 'default' ancient Israelite view of God, into which other (even contradictory) aspects were accommodated. Jesus' view of God, according to Luke, mainly emphasises the 'default' position, although punishment is not absent for loveless behaviour (Lk 12:48; 16:19-30). Interesting are the diverse receptions of this text in the rest of the Old Testament where, in some cases, reference is only made to YHWH's grace - cf. Numbers 14:18 (grace and punishment); Deuteronomy 5:9 (grace and punishment); Nehemia 9:17 (only grace); Psalm 86:15 (only grace); 103:8 (anger only temporary); 145:8-9 (only grace); Jeremiah 32:18 (focus on grace); Joel 2:13 (only grace); Jon 4:2 (only grace); grace); Jeremiah $32: 18$ (focus on gra
Nahum 1:3 (focus on punishment).

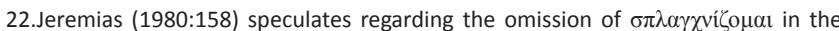
healings of the leper ( $5: 12$ contra Mk 1:41) and the feeding of the 5000 (Lk 9:11 healings of the leper ( $5: 12$ contra Mk 1:41) and the feeding of the 5000 (Lk 9:11
contra Mk 6:34): '... er vermied is beide Male, offenbar weil er sich an dem Affekt contra Mk 6:34): '... er vermied is beide Male, offenbar weil er sich an dem Affekt
Jesu stiess.' However, feeling is not absent in Luke's rendering (he expressed his

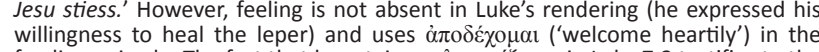

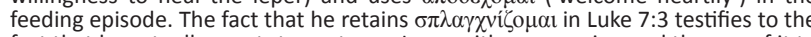
fact that he actually wants to portray a Jesus with compassion and the use of it to describe the actions of the Samaritan and the forgiving father (which indirectly refers to Jesus' own actions - cf. 15:1, 20) integrates too well with Luke's view.

TABLE 5: The requirements of compassion and their presence in Jesus' parable of the good Samaritan (Lk 10:30-37).

Requirements for of compassion (Cassel 2005)

1. Compassion is experienced and/expressed with regard to the suffering of others, not the self or the family.

2. Compassion is experienced with regard to serious suffering, not simple needs.

3. The sufferer towards whom the compassion is felt, is a victim, the suffering not being self-inflicted or perceived to be self-inflicted.

4. Compassion is generated by people imagining themselves in the predicament of the victim(s). $\dagger$

5. The compassion felt or rendered is unconditional, the victim most commonly is unaware of it and plays no conscious part in the onset of the compassion.

6. There occurs an identification with the victim, since the predicament is perceived as one's own possible fate.

7. Compassion varies amongst people, not all show it (a process of 'dis-identification' can occur) and those who show it, do so to varying degrees.

8. There is a private and social element in compassion: the feeling of the compassionate man towards somebody in society.

9. The social stance of the compassionate may play a role in the identification process.

10. The compassionate are willing to make sacrifices, to deny themselves pleasure in the action of care.

11. Compassion is not a mere feeling, but is (if possible) expressed in deeds of care.

12. Compassion is an overriding feeling that crosses national borders, recognising the common human condition.

According to Cassel (2005:437) compassion can be learned. He quotes Rousseau's Emile: 'Make him (your pupil) understand well that the fate of these unhappy people can be his, that all of their ills are there in the ground under his feet, that countless unforeseen and inevitable events can plunge him into them from one moment to the next. Teach him to count on neither birth nor health nor riches. Show him all the vicissitudes of fortune.'
The parable of the good Samaritan

2. The suffering is serious - the victim was half dead ( $\dot{\eta} \mu 1 \theta \alpha v \tilde{\eta})$

3. The man fell amongst robbers and was assaulted by them ( $\lambda \eta \emptyset \tau \alpha i \check{\varsigma} \pi \varepsilon \rho 1 \varepsilon \dot{\varepsilon} \varepsilon \sigma \varepsilon v$, $\pi \lambda \eta \gamma \alpha \grave{s} \dot{\pi} \pi(\theta \dot{\varepsilon} v \tau \varepsilon \varsigma)$.

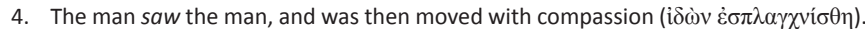

5. The robbed man was half dead, probably unconscious and did not call on the Samaritan.

6. The compassion felt by the Samaritan is not elaborated upon but can be presupposed. He approached the victim ( $\pi \rho \circ \sigma \varepsilon \lambda \theta \omega \dot{v})$.

7. The priest and the Levite passed by on the other side ( $\dot{\alpha} v \tau \imath \pi \alpha \rho \tilde{\eta} \lambda \theta \varepsilon v)$.

8. The compassion of the Samaritan constitutes the private element and the assaulted traveller the social element.

9. The clergy avoided the man (the law forbade the touching of corpses).

10. The Samaritan went out of his way to take the man to an inn and paid for everything, even future expenses.

11. The Samaritan's deeds of care are described in detail (treating the wounds and taking to the inn).

12. The pointe of the parable: a Samaritan (not a fellow-Jew) cares. 
one who has shown mercy) to refer to the Samaritan in 10:37. The parable ends with the call that the listener should

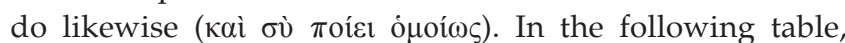
Cassel's (2005:n.p.) essential 'requirements for compassion' are listed and their remarkable ${ }^{23}$ presence in the parable of the 'compassionate' Samaritan is indicated (see Table 5).

Similar expressions of compassion can be found even when the terms are absent, as for example in the account of Jesus' healings (cf. above), his concern for the lamenting women, his healing of the high priest's ear during his arrest (22:51) and his acceptance of the penitent robber who was crucified with him (23:39-43), as well as his prayer for his crucifiers (23:34). Most of these motifs are unique to Luke's Gospel.

\section{Conclusion}

In the Handbook of positive psychology contributors endeavour to reflect scientifically on virtues which, up to now, were mainly reflected upon in the realms of philosophy and religion. In line with the endeavour of present-day psychology to be an objective science, positive psychology has sought to provide precise definitions and measurements. This has been done with limited success. To the amazement of those philosophers and theologians who, from the start, regard measurement as impossible and who regard knowledge about matters such as love, forgiveness, humility and compassion as a matter of faith, or at least personal conviction, positive psychologists have indicated that these virtues exist and are part of human nature. On the other hand positive psychologists also admit that there are aspects of these concepts that escape human measurement. For how can wisdom, humour and ethics be fully measured? It seems therefore that, besides individual reflection and meditation on these virtues, mutual discussion and reflection on them as well as experiencing them in mutual and interactive relationships, is also the way to appropriate them and simultaneously gain more profound insight into them. Surprisingly this leaves space for religion and spirituality, which as such is also consciously recognised by positive psychology (see Pargament and Mahoney's contribution on the discovery and conserving of the sacred - 2005:646-659).

There is some irony in the fact that, whereas biblical scholarship is often preoccupied with technical issues like the sources of texts, as if their understanding depends on a precise reconstruction of their origin and function in ancient contexts, psychology and spirituality would engage in cultivating the treasures which exegesis often neglects perhaps in an endeavour to gain intellectual respectability. To my mind, positive psychology has therefore a large contribution to make in the endeavours of biblical scholars who want to engage in psychological biblical criticism.

Of course Luke, like other ancient texts, is not replete with insights on positive psychology. However, to my mind, especially Luke's Gospel can be regarded as a religious

23. Remarkable, since Cassel refers nowhere to the parable and most probably made his analysis without considering Luke's Gospel. text which, if properly reflected upon - also with the aid of positive psychology - has much to contribute to the motivation and fostering of thoughts, virtues and feelings that make for worthwhile living, as it has indeed to some extent done through 2000 years of Christianity.

\section{Acknowledgements Competing interests}

The author declares that he has no financial or personal relationship(s) that may have inappropriately influenced him in writing this article.

\section{References}

Allen, J.G. 2013, 'Psychotherapy is an ethical endeavour: Balancing science and humanism in clinical practice', Bulletin of the Menninger Clinic 77(2), 103-131. http://dx.doi.org/10.1521/bumc.2013.77.2.103

Allport, G., 1961, Pattern and growth in personality, Holt, Rinehart and Winston, New York, NY.

Armstrong, T., 2007, The human odyssey: Navigating the twelve stages of life, Sterling, London.

Baltes, P.B., Glück, J. \& Kunzmann, U., 2005, 'Wisdom: Its structure and function in regulating successful lifespan development', in C.R. Snyder, S.J. Lopez (eds.) Handbook of positive psychology, pp. 327-347, Oxford University Press, New York, NY.

Batson, C.D., Ahmad, N., Lishner, D. \& Tsang, J., 2005, 'Empathy and altruism', in C.R Snyder \& S. J. Lopez (eds.), Handbook of positive psychology, pp. 485-498, Oxford University Press, New York, NY.

Bracken, P., Thomas, P., Timimi, S., Asen, E., Behr, G., Beuster, C. et al., 2012, 'Psychiatry beyond the current paradigm', British Journal of Psychiatry 201 430-434. http://dx.doi.org/10.1192/bjp.bp.112.109447

Butler-Bowdon, Tom, 2007, 50 Psychology classics: Who we are, how we think, what we do: Insight and Inspiration from 50 key books, Nicholas Brealey, London.

Cassel, E.J., 2005, 'Compassion', in C.R. Snyder \& Shane J. Lopez (eds.), Handbook of positive psychology, pp. 434-445, Oxford University Press, New York, NY.

Collin, C., Benson, N., Ginsburg, J., Grand, V., Lazyan, M. \& Weeks, M., 2012, The psychology book, Dorling Kindersley, London.

Drewermann, E., 2009, Das Lukas-Evangelium: Bilder Erinnerter Zukunft; Band 1: Lukas 1,1-12,1, Patmos, Düsseldorf.

Diener, E., Lucas, R.E. \& Oishi, S., 2005, 'Subjective well-being: The science of happiness and life satisfaction', in C.R. Snyder \& Shane J. Lopez (eds.), Handbook of positive psychology, pp. 63-63, Oxford University Press, New York, NY

Du Toit, A.B., 1965, Der Aspekt der Freude im urchristlichen Abendmahl, Keller, Wintherthur.

Ellis, E.E., 1974, The Gospel of Luke, Oliphants, London.

Emmons, R.A. \& Shelton, C.M., 2005, 'Gratitude and the science of positive psychology', in C.R. Snyder \& Shane J. Lopez (eds.). Handbook of positive psychology, pp. 459-471, Oxford University Press, New York, NY.

Erikson, E., 1963, Childhood and society, Norton, New York, NY.

Eysenck, H.J., 1973, Handbook of abnormal psychology, 2nd edn., Pitman, London.

Fensham, F.C., 1970, Exodus, POT, Callenbach, Nijkerk.

Fueter, P.D., 1986, 'The therapeutic language of the Bible', The Bible Translator 37, 309-319.

Grundmann, W., 1974, Das Evangelium nach Lukas, 7.Aufl., Evangelische Verlaganstalt, Berlin

Handelsman, M.M., Knapp, S. \& Gottlieb, M.C., 2005, 'Positive ethics', in C.R. Snyder \& S.J. Lopez (eds.), Handbook of positive psychology, pp. 731-744, Oxford University Press, New York, NY.

Hendrick, S. \& Hendrcik, C., 2005, 'Love', in C.R. Snyder \& S.J. Lopez (eds.), Handbook of positive psychology, pp. 472-484, Oxford University Press, New York, NY.

Hesse, H., 2012, Mit der Reife wird man immer jünger, Frankfurt am Mein, Suhrkamp.

Hjelle, L.A. \& Ziegler, D.J., 1976, Personality theories: Basic assumptions, research, and applications, McGraw Hill, New York, NY.

Jeremias, J., 1974, Jerusalem in the time of Jesus: An investigation into economic and social conditions during the New Testament period, SCM, London.

Jeremias, J., 1980, Die Sprache des Lukasevangeliums: Redaktion und Tradition im Nicht-Markusstoff des dritten Evangeliums, Vandenhoeck Ruprecht, Göttingen.

Kimmel, D.C., 1974, Adulthood and aging: An interdisciplinary, developmental view, John Wiley \& Sons, New York, NY.

Klein, H., 2006, Das Lukasevangelium, Vandenhoeck \& Ruprecht, Göttingen.

Lopez, S.J., Prosser, E.C., Edwards, L.M., Magyar-Moe, J.L., Neufeld, J.E. \& Rasmussen, H.N., 2005, 'Putting positive psychology in a multicultural context', in C.R. Snyder \& S.J. Lopez (eds.), Handbook of positive psychology, pp. 700-714, Oxford University Press, New York, NY. 
Maslow, A., 1970, Motivation and personality, Harper \& Row, New York, NY.

Maslow, A., 1971, The farthest reaches of human nature, Viking, New York, NY

Moltmann, J., 1973, Der gekreuzigte Gott: das Kreuz Christi als Grund und Kritik christlicher Theologie, Chr. Kaiser, München.

Mccullough, M.E. \& Witvliet, C.V., 'The psychology of forgiveness', in C.R. Snyder \& S.J. Lopez (eds.), Handbook of positive psychology, pp. 446-458, Oxford University Press, New York, N.Y.

Pargament, K.P. \& Mahoney, A. 2005, 'Discovery and conserving of the sacred', in C.R. Snyder \& S.J. Lopez (eds.), Handbook of positive psychology, pp. 646-659, Oxford University Press, New York, NY.

Piliavin, J.A. \& Charng, H.W., 1990, 'Altruism: A review of recent theory and research', American Sociological Review 16, 27-65. http://dx.doi.org/10.1146/annurev. so.16.080190.000331

Roberts, M.C., Brown, K.J., Johnson, R.J. \& Reinke, N., 2005, 'Positive psychology for children: Development, prevention, and promotion', in C.R. Snyder \& S.J. Lopez (eds.), Handbook of positive psychology, pp. 663-675, Oxford University Press, New York, NY.

Scheffler, E.H., 1993, Suffering in Luke's Gospel, Theologischer Verlag, Zürich.

Scheffler, E.H., 2011, 'Luke's view of poverty in ancient (Roman) economic context: A Challenge for today', Scriptura 106, 115-135. http://dx.doi.org/10.7833/106-0152

Scheffler, E.H., 2013, 'The assaulted (man) on the Jerusalem-Jericho road: Luke's creative interpretation of 2 Chronicles 28:15', HTS Teologiese Studies/Theological Studies 69(1), 1-8. http://dx.doi.org/10.4102/hts.v69i1.2010

Seligman, M., 2002, Authentic happiness: Using the new Positive Psychology to realize your potential for lasting fulfilment, Nicholas Brealey, London.

Seligman, M., 2005, 'Positive psychology, positive prevention, and positive therapy', in C.R. Snyder \& S.J. Lopez (eds.), Handbook of positive psychology, pp. 3-9, Oxford University Press, New York, NY.
Shapiro, S.L., Schwartz, G.E.R. \& Santerre, C. 2005, 'Meditation and positive psychology', in C.R. Snyder \& S. J. Lopez (eds.), Handbook of positive psychology, pp. 632-645, Oxford University Press, New York, NY.

Santerre, C., 2005, 'Meditation and positive psychology', in C.R. Snyder \& Shane J. Lopez (eds.), Handbook of positive psychology, pp. 632-645, Oxford University Press, New York, NY.

Simonton, D.K., 2005, 'Creativity', in C.R. Snyder \& S.J. Lopez (eds.), Handbook of positive psychology, pp. 189-201, Oxford University Press, New York, NY.

Snyder, C.R., Radn, K.L. \& Sigmon, D.R., 2005, 'Hope theory: A member of the psychology family', in C.R. Snyder\& S.J. Lopez (eds.), Handbook of positive psychology, pp. 257-276, Oxford University Press, New York, NY.

Snyder, C.R. \& Lopez, S.J. (eds.), 2005, Handbook of positive psychology, Oxford University Press, New York, NY

Suinn, R.M., 1975, Fundamentals of behavior psychology, John Wiley and Sons, New York, NY.

Tangney, J.P. 2002, 'Humility', in C.R. Snyder \& S.J. Lopez (eds.), Handbook of positive psychology, pp. 411-419, Oxford University Press, New York, NY.

Turner, N., Barling, J., Zacharatos, A., 2002, 'Positive psychology at work', in C.R. Snyder \& S.J. Lopez (eds.), Handbook of positive psychology, pp. 715-730, Oxford University Press, New York, NY.

Von Rad, G., 1970, Weisheit in Israel, Neukirchener Verlag, Neukirchen-Vluyn.

Watson, D., 2005, 'Positive affectivity: The disposition to experience pleasurable emotional states', in C.R. Snyder \& S.J. Lopez (eds.), Handbook of positive psychology, pp. 106-119, Oxford University Press, New York, NY.

Williamson, G.M., 2005, 'Aging well: Outlook for the 21st century', in C.R. Snyder \& S.J. Lopez (eds.), Handbook of positive psychology, pp. 676-687, Oxford University Press, New York, NY.

Wolter, M., 2008, Das Lukasevangelium, HNT 5, Mohr Siebeck, Tübingen. 